J. White // Cytoskeleton. - 2012. - Vol. 69, Issue 8. P. 530-544.

7. Saneyoshi, T. The $\mathrm{Ca}^{2+}$ and Rho GTPase signaling pathways underlying activity-dependent actin remodeling in the conditions of hypokinesia [Text] / T. Saneyoshi, Ya. Hayashi // Cytoskeleton. - 2012. - Vol. 69, Issue 8. - P. 545-554. doi: $10.1002 / \mathrm{cm} .21037$

8. Chevtsov, V. I. Regeneration and growth of fibers in the conditions of influence on them of the dosed directed mechanical loadings [Text] / V. I. Chevtsov // Announcer RAMN. - 2010. - Vol. 2. - P. 19-23.

9. Penzes, P. Deconstructing signal transduction pathways that regulate the actin cytoskeleton in dendritic spines [Text] / P. Penzes, M. E. Cahill // Cytoskeleton. - 2012. Vol. 69, Issue 7. - P. 426-441. doi: 10.1002/cm.21015

10. Hartstone-Rose, A. Bite Force Estimation and the Fiber Architecture of Felid Masticatory Muscles [Text] / A. Hartstone-Rose, J. M. G. Perry, C. J. Morrow // The Anatomical Record: Advances in Integrative Anatomy and Evolutionary Biology. - 2012. - Vol. 295, Issue 8. P. 1336-1351. doi: $10.1002 /$ ar.22518

11. Nemeth, N. Changes in microcirculation after ischemic process in rat skeletal muscle [Text] / N. Nemeth, T. Lesznyak, E. Brath // Microsurgery. - 2013. - Vol. 23, Issue 5. - P. 419-423. doi: $10.1002 /$ micr.10175

12. Desaki, J. A further observation of the structural changes of microvessels in the extensor digitorum longus muscle of the aged rat [Text] / J. Desaki, N. Nishida // J. Electron Microsc. (Tokyo). - 2007. - Vol. 56, Issue 6. P. 249-255. doi: 10.1093/jmicro/dfm032

\section{References}

1. Narimbetova, T. M. Ormanbaev, K. S., Bayzakova, B. U. (2011). Hypokinesia and hyperkinesia as risk factors in extreme terms. Successes of modern natural science, 5, 64-66.

2 Uzvarik, L. M., Tretiyakova, Yu. V., Belova, N. V. (2005). Research of microcirculation extremities of rats in the conditions of hypodinamia in ontogenesis. Bulletin RAMN, $115(1), 82-85$.
3. Sych, V. F., Anysymova, E. V., Kurnosova N. A. (2005). Morphogenesis of microcirculation network of superficial masticatory and digastricus muscles of rats in the conditions of hypodinamia of the jaw vehicle. Morphological lists it is Yzhevsk, 1-2, 53-55.

4. Shoichiro, O. (2010). Dynamic regulation of sarcomeric actin filaments in striated muscle. Cytoskeleton, 67 (11), 677-692. doi: $\underline{10.1002 / \mathrm{cm} .20476}$

5. Mettikolla, P., Calander, N., Luchowski, R. (2010). Observing cycling of a few cross-bridges during isometric contraction of skeletal muscle and hypokinesia. Cytoskeleton, 67 (6), 400-411. doi: 10.1002/cm.20453

6. Wang, J., Dube, D. K., White, J. (2012). Clock is not a component of Z-bands in the conditions of hypokinesia. Cytoskeleton, 69 (8), 530-544.

7. Saneyoshi, T., Yasunori, H. (2012) The $\mathrm{Ca}^{2+}$ and Rho GTPase signaling pathways underlying activity-dependent actin remodeling in the conditions of hypokinesia. Cytoskeleton, 69 (8), 545-554. doi: $10.1002 / \mathrm{cm} .21037$

8. Chevtsov, V. I. (2010). Regeneration and growth of fibers in the conditions of influence on them of the dosed directed mechanical loadings. Announcer RAMN, 2, 19-23.

9. Penzes, P., Cahill, M. E. (2012). Deconstructing signal transduction pathways that regulate the actin cytoskeleton in dendritic spines. Cytoskeleton, 69 (7), 426-441. doi: $10.1002 / \mathrm{cm} .21015$

10. Hartstone-Rose, A., Perry, J. M. G., Morrow, C. J. (2012). Bite Force Estimation and the Fiber Architecture of Felid Masticatory Muscles. The Anatomical Record: Advances in Integrative Anatomy and Evolutionary Biology, 295 (8), 1336-1351. doi: 10.1002/ar.22518

11. Nemeth, N., Lesznyak, T., Brath, E. (2013). Changes in microcirculation after ischemic process in rat skeletal muscle. Microsurgery, 23 (5), 419-423. doi: $10.1002 /$ micr. 10175

12. Desaki, J., Nishida, N. (2007). A further observation of the structural changes of microvessels in the extensor digitorum longus muscle of the aged rat. J. Electron Microsc. (Tokyo), 56 (6), 249-255. doi: 10.1093/jmicro/dfm032

Рекомендовано до публікаиії д-р біол. наук Мицкан Б. М. Дата надходження рукопису 27.10.2014

Popel' Serg, associate professor, Department of theory and method of physical culture and sport, Precarpatian national university named after Vasyl Stefanyk, Shevchenka st, 57, Ivano-Frankivsk, Ukraine, 76025

E-mail: serg_popel@mail.ru

Duma Zenoviy, professor, Department physical rehabilitation, Precarpatian national university named after Vasyl Stefanyk, Shevchenka str, 57, Ivano-Frankivsk, Ukraine, 76025

УДК 613.955: 612.014.4

DOI: $10.15587 / 2313-8416.2014 .29099$

\title{
ХРОНОБІОЛОГІЧНИЙ ПАСПОРТ ЯК ЗАСІБ ОПТИМІЗАЦІЇ РЕЖИМУ ДНЯ СТУДЕНТІВ КЛАСИЧНОГО УНІВЕРСИТЕТУ
}

\section{(C) Г. М. Тимченко}

Однією з причин погіршення стану здоров'я молоді є розузгодження внутрішніх біоритмів та базових цุиклів «прачі та відпочинку», «сну та пильнування» та режиму харчування. Питання профілактики десинхронозу у студентів полягає у плануванні та оптимізації розпорядку дня з урахуванням біоритмологічного типу людини. Хронобіологічний паспорт є системою моніторування здоров'я студентів з використанням хронобіологічного підходу.

Ключові слова: десинхроноз, адаптація, хронобіологічний тип, хронобіологічний підхід, хронобіологічний паспорт, рітмофільний тип. 
One of reasons of health state worsening of young people is inconsistency of internal biorhythms and basic cycles of «labour and rest», "dream and vigil» and diet. The problem of desynchronize prophylactics for students consists of planning and optimization of the daily routine taking into account the biorytmological types of people. There chronobiological passport is health monitoring system of students with the use of chronobiological approach.

Keywords: desynchronosis, adaptation, chronobiological type, chronobiological approach, chronobiological passport, rythmofilic type.

\section{1. Вступ}

Здоров'я як індивідуальна та суспільна цінність стає дедалі дорожчою. Дуже актуальним постає нині повсякденна турбота про збереження здоров'я та подовження тривалого повноцінного життя в умовах різкого загострення екологічних проблем, підвищення нервово-емоційних напружень в усіх сферах діяльності людини, поширення різних хвороб. Усе це ставить перед медично-біологічними, соціально-економічними та психолого-педагогічними науками низку нових фундаментальних теоретичних i практичних проблем. В роботі ми спробуємо розглянути питання погіршення стану здоров'я сучасної молоді 3 боку виявлення порушень в структурі біоритмів людини.

\section{2. Постановка проблеми}

Десинхронізацією називається стан, що характеризується розузгодженням внутрішньо- або міжсистемних ритмів, що раніше були синхронізовані. В основі десинхронізації лежить розузгодження існуючих в нормі періодів і фаз ритмів організму і зовнішнього середовища (зовнішня десинхронізація), і фазових взаємовідносин ритмів усередині організму (внутрішня десинхронізація) $[4,6]$.

При тривалій дії на організм токсичних, фізичних та інших пошкоджуючих впливів відзначається порушення добових ритмів організму, що призводить зрештою до розвитку хронічного десинхронозу. Десинхроноз $\epsilon$ першим, хоча i неспецифічним, проявом більшості патологічних процесів; його зникнення - це об'єктивний критерій одужання. Але і сам десинхроноз, у зв'язку з розбалансуванням центральних та периферичних відділів циркадіанної системи і порушенням функціонування організму, викликає патологічні зміни $[3,5]$.

Кращим загальним способом нормалізації добових ритмів є досить жорстке дотримання режиму дня і нічного відпочинку. Проте, оскільки умови, що призводять до десинхронозу, періодично виникають або постійно існують в нашому житті, то методи, що зменшують негативні ефекти, слід розглядати залежно від конкретного чинника (причини) десинхронозу.

\section{3. Літературний огляд}

У фізіології довгі роки домінувало уявлення про гомеостаз організму, під яким розуміється постійність складу i властивостей внутрішнього середовища i стійкість фізіологічних функцій організму. Це представлення глибоко проникло не лише у буденну i наукову свідомість, але i в практичну діяльність. Проте, у зв'язку з ритмічністю будь-якої функції організму, потрібного значення того або іншого нормативу спостерігається лише в певні години доби $[1,5]$. Тому гомеостаз слід розуміти не як стійкість внутрішнього середовища, а як коливальний процес - ритмостаз, або гомеокінез.

Циркадіанна система організму в кожен період часу, щоб вижити зобов'язана пристосовуватися, міняючи свої параметри, до дещо іншого тимчасового середовища, чим у попередній період часу, тобто знаходитися завжди в стані десинхроноза тієї або іншої міри вираженості, але невеликому при звичайному режимі життя. Тим самим природний десинхроноз - це деяка міра напруги, яка, згідно Г. Селье, є неодмінною ознакою життя [1].

Звідси стає зрозумілою наявність природного блукання фази циркадіанних ритмів, яке і вносить деяку міру невпорядкованості. Зона блукання фази це той плацдарм, на якому йде боротьба між синхронізацією та десинхронізацією. Чим ближче положення фази до середньої зони блукання, тим більше виражений процес синхронізації. Чим більше змішення акрофази до меж цієї зони, тим більше переважає десинхронізація в межах норми.

Вихід же акрофази із зони блукання означає перехід природного десинхроноза в патологічний. Ми бачимо тим самим, що межа між нормою i патологією розмита, вона є деяким переходом. Існує декілька проявів природного десинхроноза. Ресинхронізація в межах зони блукання фази може бути названа як десинхроноз, що компенсується, або прихований десинхроноз невеликої міри, який характеризується поєднанням елементів стадії тривоги i резистентності у рамках загального адаптаційного синдрому Г. Селье $[1,5]$.

Крім того, можна виділити сезонний фізіологічний десинхроноз. Відомо, що міра розсинхронізації циркадіанної системи організму змінюється впродовж року: взимку вона нижча, а навесні і восени підвищується. Звідси стає зрозуміло, чому навесні і восени відбувається загострення ряду хронічних захворювань.

Причина сезонного десинхроноза полягає в тому, що влітку і взимку фаза циркадіанних ритмів займає різне положення в добовому ритмі. Положення акрофази в різні сезони року можуть відрізнятися на декілька годин. У перехідні сезони (осінь і весна) відбувається рух фаз від літньої до зимової і назад. А оскільки існують ритми з різною інертністю (рухливі і інертні), то вони перебудовуються з різною швидкістю.

Вираженість сезонного природного десинхроноза вище десинхроноза, що компенсується, але значно нижче того, що виникає при трансмеридіональних перельотах або змінній роботі. Весняний фізіологічний десинхроноз накладається на штучний десинхроноз, пов'язаний 3 переміщенням 
годинникової стрілки, і тому, на жаль, він є досить небезпечним для осіб з хронічними захворюваннями, що входять в тріаду симптомів десинхроноза, і в цих випадках, являючись дезадаптивним, відповідає третьому етапу стресу за Г. Сельє.

Існує ще один прояв фізіологічного десинхроноза - це онтогенетичний десинхроноз, який в нормі характерний для дітей і літніх людей.

Рядом дослідників [2, 4, 6] було відмічено, що дитячий організм дуже схильний до десинхронозу. Це пояснюється цілим рядом причин: незрілістю окремих систем організму, відсутністю соціального досвіду, слабким розвитком регуляторних систем організму, та ін. Дитячо-підлітковий десинхроноз це ознака нормального стану організму, оскільки він $\epsilon$ не одиничним виключенням, а характеризує велику частину популяції учнів. Відомо, що у дітей $\mathrm{i}$ підлітків біоритмологічний тип активності ще не сформований, але є генетичні передумови до його становлення. Тому в них виділяють так званий «умовний біоритмологічний тип». Виявилось, що у школярів 3 умовно-вранішнім профілем стомлюваність була менше в першу половину дня [2, 5]. Оскільки обстежені діти навчалися в першу зміну, то меншу стомлюваність учбового навантаження в цей час слід пояснити адекватністю зміни навчання біоритмологічному профілю організму. Необхідно відмітити, що у школярів поза учбовим процесом і у дітей, що навчаються в школі, але ознак стомлення у кінці уроків не мають, має місце висока тимчасова синхронізація розумової працездатності, частоти сердечних скорочень, температури тіла i артеріального тиску.

Таким чином, дані, отримані біоритмологами [2, 4-6], показують, що існуюча система організації учбового процесу не відповідає оптимальним тимчасовим взаємовідносинам багатьох школярів 3 довкіллям (часом навчання в школі), що призводить до розузгодження психофізіологічних функцій організму, тобто десинхронозу. Проте оптимальні межі цього десинхронозу ще невивчені до такої міри, щоб говорити про хронобіологічні нормативи зростаючого організму.

Дорослий організм, характеризується найбільшою узгодженістю окремих циркадіанних ритмів. Проте розузгодження ритмів починається саме в цьому віці. Так, вже з 25-30 років у деяких людей починають з'являтися ознаки погіршення сну, які надалі посилюються. Поступово зменшується здатність синхронізувати свої ритми зі змінами циклу світло-темрява. Зрештою це призводить до прогресуючої старечої десинхронізації. Вважають [4, 5], що старечий онтогенетичний десинхроноз $\epsilon$ одним 3 проявів генетично запрограмованого механізму обмеження індивідуальної тривалості життя. Слід думати, що віковий десинхроноз в дитячо-підлітковому і старечому віці якісно відрізняються один від одного, але мають одно і те ж значення - пристосування організму до місця існування, що здійснюється різними способами.

В процесі онтогенезу змінюються амплітуднофазові відносини добових ритмів. Згідно 3
Г. Д. Губіним, увесь онтогенез можна представити у формі спіралі 3 поступово зростаючими оборотами (збільшення амплітуди добового ритму), а на пізніх етапах онтогенезу - 3 їх згасанням. Виявилось $[1,5]$, що зона оптимуму життя знаходиться в межах 20-55 років, а загальна тривалість життя (до загасання осциляції) прогнозується до 150 років. Отже, можна виділити природний і штучний (свідомий, або соціальний) десинхроноз. В обох випадках він може бути адаптивним і дезадаптивным залежно від міри розсинхронізації циркадіанної системи i реакції організму на сам процес десинхроноза.

\section{4. Аналіз режиму дня студентів} використанням хронобіологічних паспортів

Добовий режим - це і регулярне раціональне харчування, i повноцінний, досить тривалий сон, i розумні щоденні фізичні навантаження. Для профілактики втоми і стимуляції працездатності можна вдатися до фізичних вправ на протязі робочого дня. Життя доводить, що будь-кому під силу виконати набагато більший обсяг роботи, якщо достатньо відпочивати i використовувати робочі години раціональніше. Для того щоб правильно організувати режим, потрібно врахувати особливості добової працездатності. Як було уже зазначено [2, 5], за динамікою працездатності людей можна умовно розділити на три категорії: аритмічний, вечірній та ранковий типи. За даними досліджень приблизно половина людей відноситься до аритмічного типу. Вони легко пристосовуються до будь-якого режиму праці. Близько 20--30 \% населення становить вечірній тип. Решта відносяться до ранкового типу. Встановити до якого типу належить людина, можна за допомогою використання різних опитувальників та тестів.

Особливе значення для збереження здоров'я та високої працездатності мають психічний стан, оптимізм, почуття гумору, впевненість в собі. Кожній людині надзвичайно важливо навчитися вибирати оптимальний час для того чи іншого виду роботи, що збігається 3 піком добової, тижневої, місячної працездатності. Тому для побудова оптимального режиму дня, який би співпадав 3 ритмофільним типом людини, та забезпечив високу ефективність як праці так і відпочинку впродовж доби, нами було запропоновано «Хронобіологічний паспорт», який містить в собі набір методик задля оцінки біоритмів людини.

У дослідженні біоритмів прийняли участь 70 студентів (64 дівчини та 6 юнаків) Харківського національного університету імені В. Н. Каразіна віком 18-19 років. Відміни в групах надалі ми проводили 3 використанням хронобіологічного підходу та без урахування статевих ознак у зв'язку 3 тим, що статева приналежність не впливає на виникнення десинхронозів. Студенти заповнювали хронобіологічні паспорти впродовж семестру на заняттях та вдома. Аналіз заповнених паспортів проводився зі згоди та власного бажання учасників.

Виявлення біоритмологічних типів проводили за допомогою наступних методик: 
- тест-питальник О. Остберга, який дає змогу виявити хронобіологічний тип людини за допомогою вивчення режиму дня;

- питальник Г. Ламперта, який дає змогу визначити ритм працездатності протягом дня;

- тест Г. Хільдебранда, який дає змогу визначити тип добової працездатності за співвідношенням кількості серцевих скорочень до кількості вдихів, які вимірюються відразу після пробудження.

За результатами проведених анкетних тестів, виявлено, що близько 50 \% обстежених студентів в даній групі, становлять особи 3 аритмічним хронобіологічним типом, $30 \%$ - вечірнім та $20 \%-$ ранковим (рис. 1).

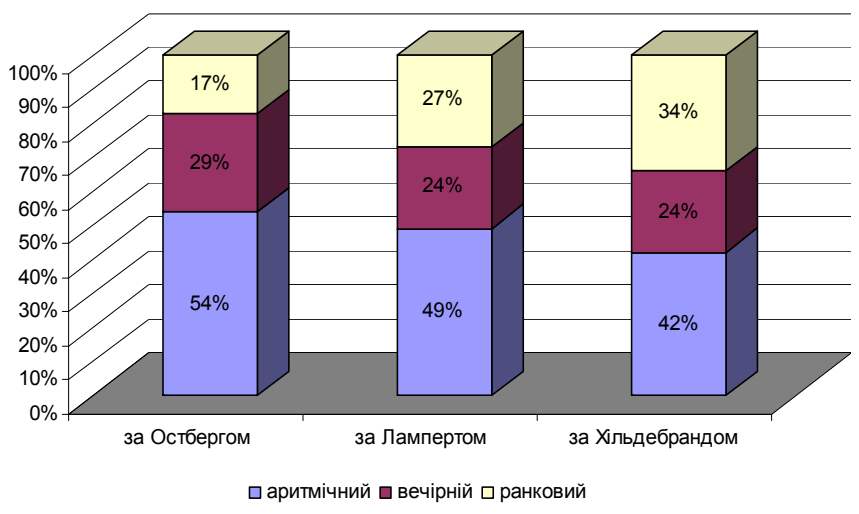

Рис. 1. Біоритмологічні типи студентів за різними методиками, \%

Розподіл адаптаційного потенціалу, визначеного за методикою Р. М. Баэвського, показав, що задовільна адаптація спостерігається у $43 \%$ студентів аритмічного хронобіологічного типу, $20 \%$ - вечірнього та $14 \%$ - ранкового, напруга механізмів адаптація виявлена лише у $3 \%$ студентів вечірнього хронобіологічного типу, незадовільна адаптація спостерігається у $3 \%$ студентів ранкового, $7 \%$ аритмічного та $6 \%$ вечірнього хронобіологічних типів, зрив адаптаційних механізмів виявлений лише у 4 \% студентів аритмічного хронобіологічного типу (рис. 2).

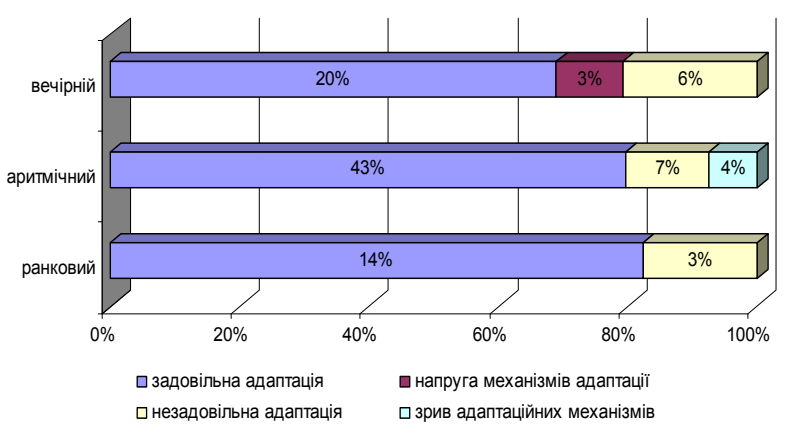

Рис. 2. Розподіл показників адаптаційного потенціалу у студентів з різним хронобіологічним типом, \%

Більш ретельний аналіз стану показників адаптації за методикою Баєвського показав (рис. 3), що добрі та задовільні адаптаційні можливості мають студенти 3 аритмічним хронобіологічним типом (71 \% та $53 \%$ відповідно), напруга механізмів адаптації виявлена переважно у осіб 3 вечірнім хронобіологічним типом, незадовільна адаптація виявлена також у $33 \%$ студентів вечірнього хронобіологічного типу. Отримані дані свідчать про те, що саме у осіб аритмічного хронобіологічного типу відбуваються певні адаптаційні зміни в бік узгодження внутрішніх датчиків часу із зовнішніми, якими $\epsilon$ соціальні датчики режиму навчання та активності.

Аналіз отриманих даних за критерієм D Coмepa, показав, що при зміні хронобіологічного типу працездатності з ранкового на вечірній, відбувається невеликий зсув адаптаційних механізмів, який ймовірно призводить до поламки адаптаційних механізмів.

Аналіз даних, отриманих за методикою «Рефлекс на час», дав змогу оцінити індивідуальну здатність до відтворення 15 сек проміжку часу та показати, що у 95 \% студентів вечірнього хронобіологічного типу при 5-ти кратному повторенні одного і того ж завдання розвивається втома (рис. 4). Менш вразливими до втоми $\epsilon$ студенти 3 аритмічним (31,6 \% випадків) та ранковим (16,7 \% випадків) хронобіологічними типами.

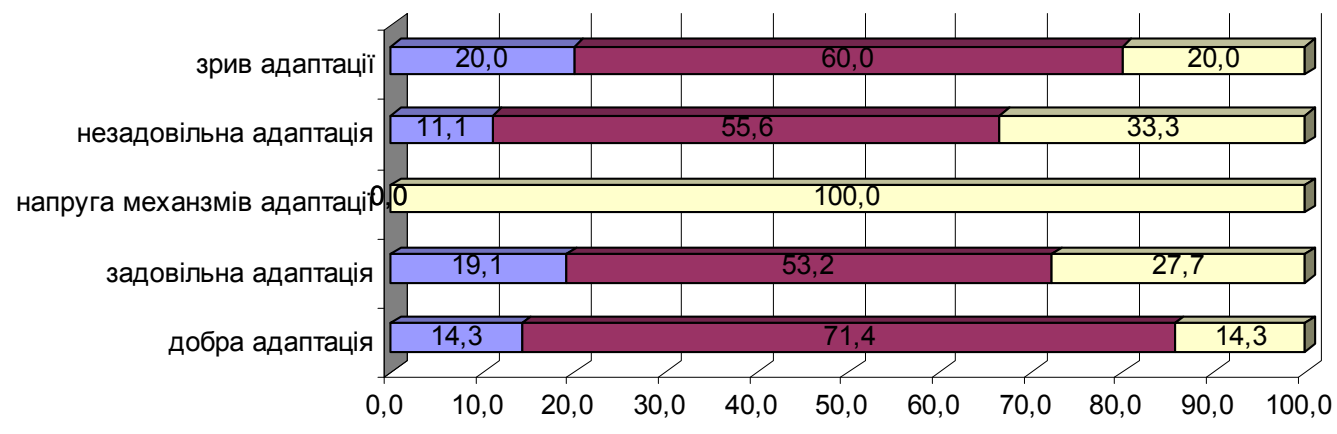

$\square$ ранковий $\square$ аритм. $\square$ вечірній

Рис. 3. Розподіл показників адаптаційного потенціалу у студентів в групах з різними хронобіологічними типами, \% 


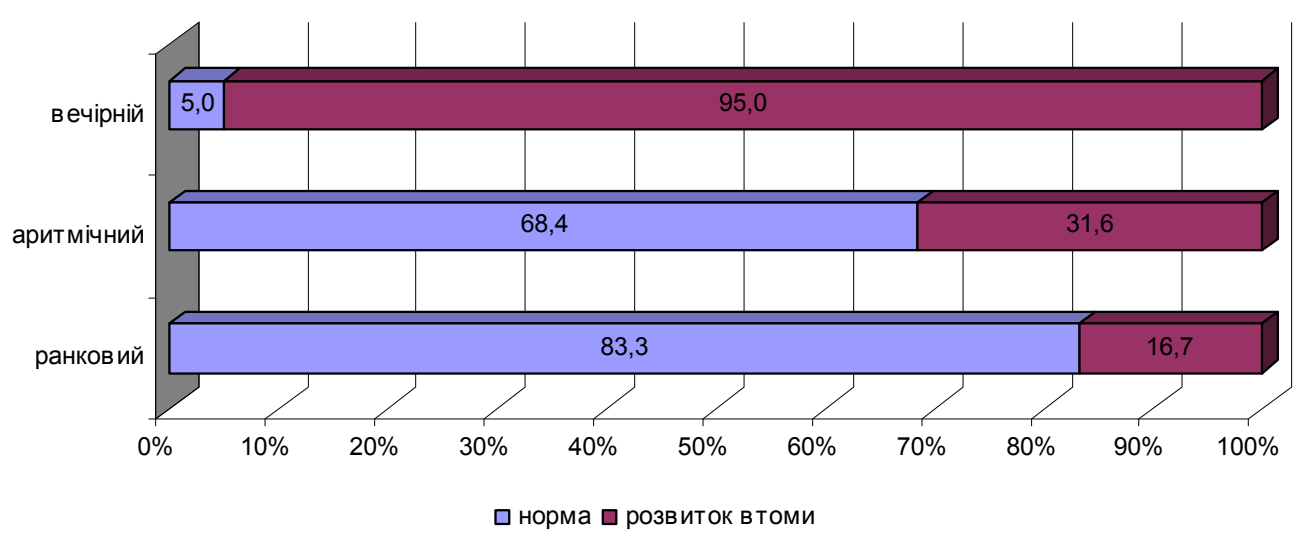

Рис. 4. Розподіл показників тесту «Рефлекс на час» у студентів з різними хронобіологічними типами, \%

Аналіз отриманих даних за критерієм D Coмера, показав, що при зміні хронобіологічного типу працездатності з ранкового на вечірній, відбувається наростання втоми.

Адаптаційні можливості також можна визначати за здатністю оцінки індивідуальної хвилини. Слід пам'ятати про те, що в патологічній фізіології визначено, що при захворюваннях часові характеристики змінюються - індивідуальна оцінка часу скорочується. Так, близько третини студентів ранкового та аритмічного хронобіологічних типів (75\% та 73,7 \% студентів) мають добру адаптацію до різних фізичних та психічних навантажень - здатність оцінки індивідуальної хвилини коливається в межах 55-65 сек. В групі студентів вечірнього хронобіологічного типу кількість студентів зі схожими значеннями показників становила лише $45 \%$ (рис. 5). Слід зазначити, що так званою «групою ризику» щодо можливих проявів десинхронозів $\epsilon$ саме студенти вечірнього хронобіологічного типу із здатністю оцінки індивідуальної хвилини в межах 46-47 сек, що свідчить про погану адаптацію до дії фізичних навантажень.

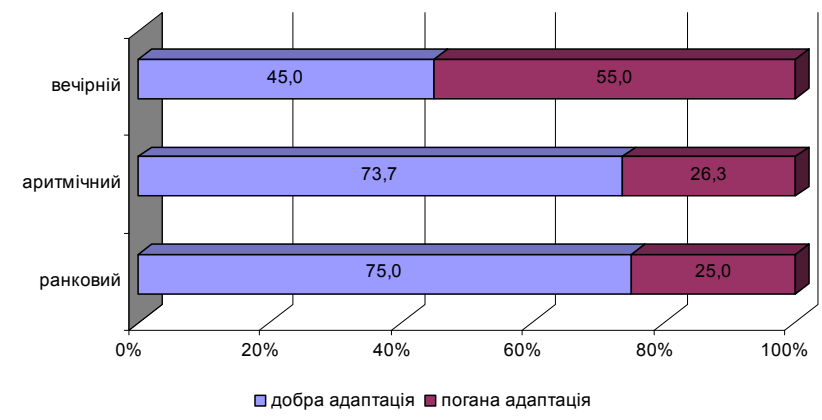

Рис. 5. Розподіл показників тесту

«Індивідуальна хвилина» у студентів з різними хронобіологічними типами, \%

Аналіз отриманих даних за критерієм D Coмера, показав, що при зміні хронобіологічного типу працездатності з ранкового на вечірній, відбувається погіршення показників перенесення фізичних навантажень 3 подальшою психічною неврівноваженістю.
Аналіз циклу «сон - пильнування» дав змогу оцінити якість та кількісні показники тривалості сну у студентів з різними хронобіологічними типами. Так, аналіз отриманих даних показав, що існує вірогідна різниця в показниках тривалості сна та годин відпочинку та сну в залежності від хронобіологічного типу (за критерієм $X^{2}$ ). Студенти 3 ранковим хронобіологічним типом переважно обирають для сну проміжки часу: від 00 до 7.00 (у $25 \%$ випадків), від 22.00 до 6.00 (у $25 \%$ випадків) та від 23.00 до 8.00 (у 16,7\% випадків); студенти 3 аритмічним хронобіологічним типом переважно обирають проміжки часу: від 00 до 7.00 (23,7 \% випадків), від 00 до 8.00 (26,3\% випадків), від 23.00 до 8.00 (15,8\% випадків); студенти 3 вечірнім хронобіологічним типом обирають проміжки часу: від 00 до 7.00 (20\% випадків) та з 23.00 до 7.00 (20\% випадків) (рис. 6). Хоча необхідна кількість годин для сну для здорової людини повинна складати 10-12 годин.

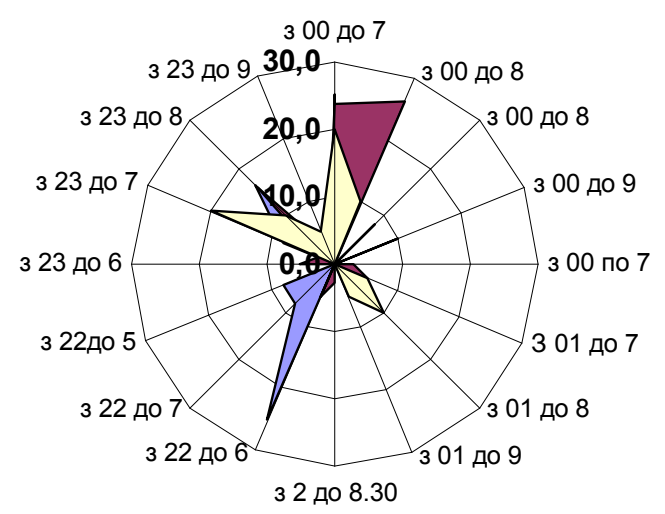

$\square$ ранковий $\square$ аритмічний $\square$ вечірній

Рис. 6. Розподіл годин сну серед студентів 3 різними хронобіологічними типами, \%

Аналіз годин пробудження після нічного сну серед студентів 3 різними хронобіологічними типами показав, що студенти з ранковим хронобіологічним типом переважно просинаються у 7.00 та 8.00 годин (по $25 \%$ випадків), 3 аритмічним хронобіологічним 
типом - у 9.00 та 10.00 (39,5 \% та 26,3 \% відповідно), 3 вечірнім хронобіологічним типом - у 9.00 та 11.00 (30\% та $25 \%$ відповідно) (рис. 7). Слід зазначити, що такий вільний графік пробудження зовсім не пов'язаний із ритмом «праці та відпочинку», згідно 3 яким навчальні заняття починаються з 8.00.

Аналіз отриманих даних за критерієм D Coмера, показав, що при зміні хронобіологічного типу працездатності з ранкового на вечірній, відбувається зсув до більш пізнього пробудження, що $є$ свою чергу природним явищем.

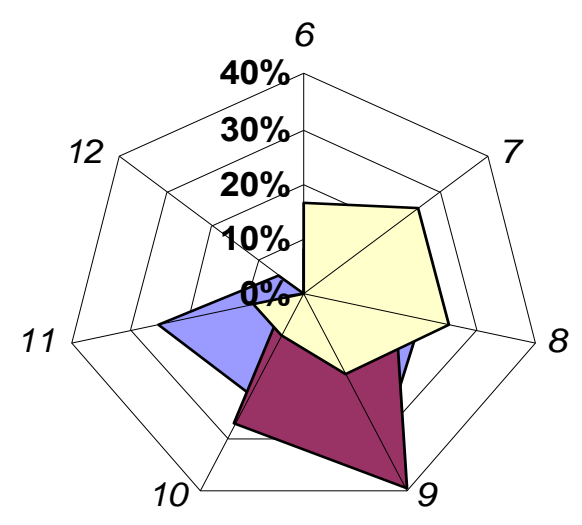

\section{$\square$ Вечірній $\square$ Аритмічний $\square$ Ранковий}

Рис. 7. Розподіл годин пробудження після нічного сну серед студентів з різними хронобіологічними типами, \%

Аналіз годин інтенсивної працездатності ми поділили на три діапазони: 37.00 до 21.00; з 10.00 до 18.00 та з 11.00 до 20.00. Аналіз отриманих даних за критерієм $X^{2}$ показав, що інтенсивність працездатності під час певного діапазону годин не пов'язана із певним хронобіологічним типом, що можна пояснити інтенсифікацією процесу навчання та відсутність сталого розкладу занять.

Аналіз розподілу годин інтенсивної ранкової працездатності та протягом дня серед студентів 3 різними хронобіологічними типами вказує на поодинокі випадки інтенсивної працездатності серед студентів ранкового хронобіологічного типу протягом доби: 37.00 до 21.00 та $з 8.00$ до 16.00 (загальна тривалість від 8 до 16 годин) у порівнянні зі студентами 3 вечірнім хронобіологічним типом: 3 8.00 до $14.00,38.00$ до 16.00 та 39.00 до 15.00 (загальна тривалість 6-8 годин)

Аналіз розподілу годин інтенсивної працездатності протягом дня серед студентів вказує на те, що найбільш сприятливим періодом денної працездатності $€$ період 310.00 до $15.00-18.00$ незалежно від хронобіологічного типу.

Аналіз розподілу годин інтенсивної денної працездатності серед студентів вказує на те, що найбільш сприятливим періодом денної працездатності для студентів 3 ранковим хронобіологічним типом є період з 11.00 до 13.00 та 3 11.00 до 17.00; для студентів 3 вечірнім хронобіологічним типом - період з 11.00 до 17.00 та з 13.00 до 19.00. Для студентів 3 аритмічним типом переважних годин денної працездатності не виявлено, вони відзначили різні годинні інтервали.

Більшість сучасних людей живе в активному темпі сучасного життя та жаліється на брак часу протягом доби, тому до «Хронобіологічного паспорту» ми додали питання, відповідь на яке дала змогу підтвердити висунуте припущення. За результати отриманих даних $71 \%$ студентів аритмічного та $50 \%$ студентів вечірнього хронобіологічних типів жаліється на нестачу часу, в той час як $50 \%$ студентів 3 ранковим хронобіологічним типом відзначили, що встигають виконати всі заплановані справи.

\section{5. Висновки}

Аналіз літературних даних 3 питань профілактики десинхронозів показав, що немає ефективнішого засобу профілактики десинхронозів, ніж планування та оптимізація розпорядку дня 3 урахуванням біоритмів людини. В ході проведених досліджень виявлено недостатність уваги обліку біоритмологічних особливостей студентів при плануванні базових циклів «праці та відпочинку», «сну та пильнування». Аналіз даних хронобіологічних паспортів показав, студенти саме вечірнього та аритмічного типу мають хронічні десинхронози, або схильність до них, що в свою чергу потребує перегляду розпорядку дня студентів, врахування індивідуальних особливостей при плануванні режимів «сну та пильнування», «праці та відпочинку», «активності та спокою», а також періодів денної працездатності та ритму харчування.

\section{Література}

1. Коляда, Т. И. Адаптационный синдром и иммунитет [Текст] / Т. И. Коляда, Ю. Л. Волянский, И. В. Васильев, В. И. Мальцев. - Харьков: Основа, 1995. - 368 с.

2. Тимченко, Г. М. Хронобіологічний підхід щодо оцінки стану здоров'я студентів [Текст] / Г. М. Тимченко // Вісник Харківського національного університету імені В. Н. Каразіна. Серія: Біологія. - 2011. - Вип. 13, № 947. C. 190-195.

3. Тимченко, А. Н. Хронобиологический паспорт [Текст] : Метод. пос. / А. Н. Тимченко. - Курс «Основы биоритмологии». - Харьков: ХНУ имени В. Н. Каразина, 2012. - C. 66-72.

4. Комаров, Ф. И. Хронобиология и хрономедицина [Текст] / Ф. И. Комаров, С. И. Рапопорт. - М.: Триада, 2000. $-488 \mathrm{c}$.

5. Агаджанян, Н. А. Хронофизиология, хронофармакологя и хронотерапия [Текст]: монографія / Н. А. Агаджанян, В. И. Петров, И. В. Радиш, С. И. Краюшкин. - Волгоград: Изд-во ВолГМУ, 2005. - 336 с.

6. Шапошникова, В. И. Хронобиология и спорт [Текст] / В. И. Шапошникова, В. А. Таймазов. - М.: Советский спорт, 2005. - 180 с.

\section{References}

1. Kolyada, T. I., Volyanskij, U. L., Vasil'ev, I. V., Mal'cev, V. I. (1995). Adaptacijnij sindrom i immunitet. Kharkov: Osnova, 368.

2. Timchenko, G. M. (2011) Chronobiologichnij pidhid chodo ocinki stanu zdorovya studentiv. Visnik Kharkivskogo 
nacionalnogo universiteta imeni V. N. Karazina. Serija: Biologija, 13 (947), 190-195.

3. Timchenko, A. N. (2012). Chronobiologichnij passport. Metodicheskoe posobie. Kurs «Osnovi biorythmologii». Kharkiv: Kharkiskij nacionalnij universitet imeni V. N. Karazina, 66-72.

4. Komarov, F. I., Rapoport, S. I. (2000). Chronobiologija i chronomedicina. Moskva: Triada, 488.
5. Agadganjan, N. A., Petrov, V. I., Radysh, I. V., Kraushkin, S. I (2005). Chronofiziologija, chronofarmocologija i chronoterapija. Volgograd: Izdztelstvo Volgogradskogo gosudarstvennogo medicinskogo universiteta, 336.

6. Shaposhnikova, V. I., Tajmazov, V. A. (2005). Chronobiologija i sport. Moskva: Sovetskij sport, 180.

Рекомендовано до публікайї д-р біол. наук Клімова О. М. Дата надходження рукопису 31.10.2014

Тимченко Ганна Миколаївна, кандидат біологічних наук, доцент, кафедра валеології, Харківський національний університет ім. В. Н. Каразіна, пл. Свободи, 6, м. Харків, 61077

E-mail: Anch5555@, rambler.ru

\begin{abstract}
УДК 612.821.3+572.025+158.983.2
DOI: $10.15587 / 2313-8416.2014 .28980$
\end{abstract}

\title{
ОЦІНКА ФУНКЦІОНАЛЬНОГО РОБОЧОГО СТАНУ ТА ПРАЦЕЗДАТНОСТІ ОСІБ РІЗНОГО ВІКУ В УМОВАХ РОЗУМОВИХ НАВАНТАЖЕНЬ
}

\author{
(C) Н. В. Харковлюк-Балакіна, Ю. П. Горго
}

Розглянуто результати оцінок функиіонального робочого стану осіб різного віку в умовах розумових навантажень. Доведено, щзо для оиінки оптимальної розумової працездатності людини необхідним $\epsilon$ застосування показників функиіонального віку та темпу старіння з метою визначення впливу вікового фактору на професійну адаптацію персоналу, зокрема осіб, щзо знаходяться в умовах підвищеного нервово-емоиійного напруження.

Ключові слова: функиіональний робочий стан, вікова динаміка працездатності, темп старіння людини.

The results of functional state evaluation of working people of all ages in mental stress terms were reviewed in this research. It has been proved that for estimation of optimum mental capacity a person needs the use of functional age and aging rate to determine the effect of the age factor on the adaptation of professional staff, including persons in conditions of increased neuro-emotional stress.

Keywords: functional working condition, working capacity age dynamics, aging rate.

\section{1. Вступ}

Сучасні демографічні дані свідчать про постійне зростання кількості осіб похилого віку в загальній структурі населення на тлі прогнозування тенденції дефіциту кваліфікованих працівників, що визначає актуальність геронтологічних досліджень по вирішенню окремих аспектів проблеми професійного старіння людини, спрямованих на пошук балансу між ефективністю діяльності та фізіологічної «ціни» іiі забезпечення. 3 іншого боку, еволюція розвитку науково-технічних досягнень людства максимально наблизила суспільство до впроваджень інформативних технології, однак проблема впливу "людського чинника" не стає менш глобальною та перетинається 3 багатьма сферами професійної діяльності, у зв'язку з чим особливого значення набуває проблема розробки й удосконалення засобів контролю та корекції стану здоров'я персоналу та ефективності реалізації їх професійних навичок.

На разі життєдіяльність сучасної людини не у повній мірі відповідає потребам організму у руховій активності. Окремим чинником ризику багатьох патологічних змін в осіб розумової праці виступають реакції гіпокінетичного синдрому, серед яких зниження функціональних резервів серцево-судинної та дихальної систем, порушення опорно-рухового апарату, на тлі тенденції зростання загальної маси тіла тощо, що дає підставу для пошуку ефективних засобів своєчасної діагностики донозологічних станів людини та корекції працездатності в умовах розумового навантаження.

\section{2. Постановка проблеми}

Працездатність людини, являючи собою фізіологічною основою продуктивності праці, надає можливість реалізації знань, умінь і досвіду людини. Зокрема, в природних, штучно створених та екстремальних умовах праце діяльності розумова працездатність лімітується динамікою функціонального робочого стану, пов'язаного зі впливом різноманітних екзо- та ендогенних факторів (Горого Ю. П., 2004) [1]. Однак пошук прийомів об'єктивної оцінки забезпечення оптимальної працездатності в осіб різного віку, від яких залежать надійність i ефективність виконуваної роботи, залишається однією з актуальних завдань у фізіології праці, оскільки динаміка функціональних станів людини лінійно не відображає зміни рівня працездатності в умовах розумових навантажень. 